\title{
Rheumatoid lung
}

\author{
Rita Gonçalves Simões, Helena Maia
}

Department of Internal Medicine, Centro Hospitalar Entre Douro e Vouga, Santa Maria da Feira, Portugal

\section{Correspondence to} Dr Rita Gonçalves Simões, risa.simoes@gmail.com

Accepted 19 April 2015

\section{(DrossMark}

To cite: Simões RG Maia H. BMJ Case Rep Published online: [please include Day Month Year] doi:10.1136/bcr-2014208194

\section{DESCRIPTION}

Rheumatoid arthritis (RA) is one of the most common forms of chronic arthritis affecting, especially, the osteoarticular system. However, in about $40 \%$ of patients, there are also extra-articular manifestations. ${ }^{12}$

The authors present the case of a 55-year-old man, a smoker, sent to the internal medicine outpatient clinic in 2007 with a symmetric polyarthritis developing over 4 months and left pleuritic chest pain for several weeks. Examination showed diminished chest breath sounds and hypoxia.

The investigation confirmed RA (rheumatoid factor and anticitrullinated protein antibody positive) and the lung images showed bilateral apical bullae, pulmonary nodules, pleural effusion and mediastinal adenopathies. The pleural effusion study revealed an exudate with low glycose. The cultures of sputum and pleural fluid (bacterial and MTB) were both negative. A biopsy of the mediastinal adenopathies and lung parenchyma revealed rheumatoid granuloma.

The patient was treated with prednisolone (maximum $60 \mathrm{mg} /$ day) and methotrexate $10 \mathrm{mg} /$ week for about a year, but his respiratory

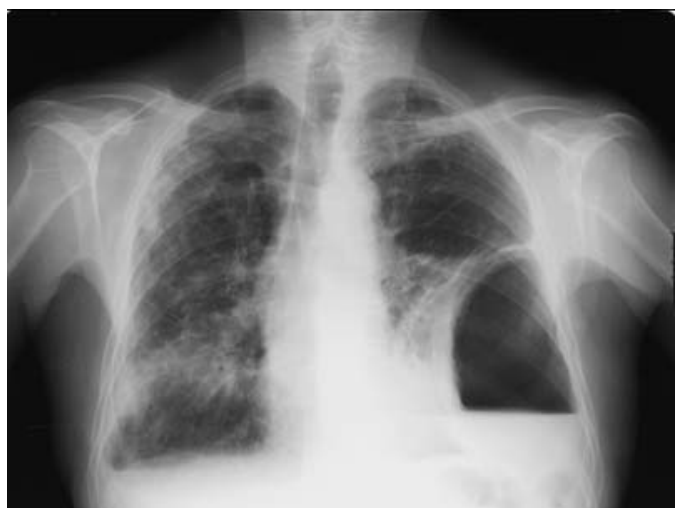

Figure 1 Rheumatoid lung, with different kinds of pulmonary involvement due to rheumatoid arthritis: fibrosis, hydropneumothorax and pleural effusion. capacity continued to decrease, with pulmonary fibrosis, worsening of pulmonary function tests and frequent infectious exacerbations needing hospitalisation and intravenous antibiotics. The methotrexate was substituted by sulfasalazine because of low compliance and possible lung side effects. The pleural effusion became refractory causing a hydropneumothorax (figure 1). Pleurodesis was successfully performed. The patient is now under home oxygen therapy and without specific treatment for the RA, as he stopped attending consultations.

The interest of this case lies in the fact that the extensive pulmonary involvement associated the weak therapeutic compliance worsens the prognosis of a potentially treatable disease. ${ }^{3}$

\section{Learning points}

- Rheumatoid arthritis (RA) is a multisystem disease affecting not only the osteoarticular system, but also capable of impairing multiple extra-articular sites, including the lungs.

- The pulmonary involvement in RA can be extensive, with parenchymal destruction caused by rheumatoid granulomas and evolving to fibrosis.

Competing interests None declared.

Patient consent Obtained.

Provenance and peer review Not commissioned; externally peer reviewed.

\section{REFERENCES}

1 Lipsky P. Rheumatoid arthritis. In: Fauci AS, Casper DL, Longo DL, et al. eds. Harrison's principles of internal medicine. 17th edn. New York: McGraw Hill, 2008:2083-92.

2 Tanoue LT. Pulmonary manifestations of the collagen vascular diseases. In: Fishman AP, ed. Fishman's manual of pulmonary diseases and disorders. 3rd edn, 2002. P396-400.

3 O'Dell JR. Therapeutic strategies for rheumatoid arthritis. N Eng/ J Med 2004;350:2591-602.

Copyright 2015 BMJ Publishing Group. All rights reserved. For permission to reuse any of this content visit http://group.bmi.com/group/rights-licensing/permissions.

BMJ Case Report Fellows may re-use this article for personal use and teaching without any further permission.

Become a Fellow of BMJ Case Reports today and you can:

- Submit as many cases as you like

- Enjoy fast sympathetic peer review and rapid publication of accepted articles

- Access all the published articles

- Re-use any of the published material for personal use and teaching without further permission

For information on Institutional Fellowships contact consortiasales@bmjgroup.com

Visit casereports.bmj.com for more articles like this and to become a Fellow 